\title{
PEMETAAN TENAGA KEPENDIDIKAN TETAP DI FAKULTAS EKONOMI UNIVERSITAS ISLAM INDONESIA
}

\author{
Suhartini \\ Program Studi Manajemen, Fakutas Ekonomi UII
}

Abstrak

Pemetaan tenaga kependidikan di FE UII bertujuan untuk: (1) mengetahui jumlah kebutuhan tenaga kependidikan tetap yang sesuai dengan beban kerja yang ada, (2) menciptakan kesesuaian antara penempatan dengan keinginan dari tenaga kependidikan tetap, (3) melaksanakan program pengembangan tenaga kependidikan tetap, dan (4) mendapatkan kesesuaian antara kompetensi tenaga kependidikan tetap dengan kebutuhan pekerjaan. Tahap pemetaan: (1) menghitung kebutuhan tenaga kependidikan tetap ideal dengan mempertimbangkan jumlah mahasiswa, (2) mengidentifikasi sisa usia produktif, (3) menganalisis ketepatan penempatan yang saat ini ada, (4) mengidentifikasi aktivitas pengembangan yang harus dilakukan untuk mewujudkan keinginan atas pekerjaan, (5) menyusun matriks penilaian kebutuhan pelatihan tenaga kependidikan tetap. Hasil pemetaan menunjukkan bahwa: (1) berdasarkan data semester ganjiI 2011/2012, rasio tenaga kependidikan: mahasiswa, 1:77, berada pada kategori ideal, (2) jumlah tenaga kependidikan tetap yang memiliki usia produktif > 4 tahun sebanyak 4 orang, (3) jumlah tenaga kependidikan tetap yang saat ini bekerja pada pekerjaan yang tidak sesuai dengan keinginannya sebanyak 2 orang, dan (4) jumlah tenaga kependidikan tetap yang memiliki keinginan untuk mengembangkan diri dan meraih pekerjaan yang lebih tinggi sebanyàk 11 orang.

Kata Kunci : Pemetaan, usia produktif, pengembangan diri

\section{PENDAHULUAN}

Appelbaum \& Kamal (2000) menyatakan bahwa sumber daya manusia (SDM) merupakan being the most important asset bagi suatu organisasi. Timbulnya persaingan global yang semakin kompetitif saat ini menyebabkan organisasi harus semakin menyadari pentingnya efisiensi dan efektivitas dalam mengelola SDM untuk memantapkan daya saing perusahaan. Suatu organisasi agar mampu bersaing dan tetap survive dalam lingkungan yang selalu berubah, periu mengubah kebutuhan manajemen dan beralih ke market for management talent. Karatepe \& Ekiz (2004) menyatakan bahwa untuk menghadapi kondisi tersebut, perusahaan perlu memberi perhatian untuk melakukan restrukturisasi organisasi dan menerapkan pengelolaan yang melindungi semua karyawan dalam organisasi.

Pemetaan karyawan merupakan salah satu metode untuk mencatat aktivitas tenaga kependidikan. Dengan melakukan pemetaan karyawan, organisasi diharapkan mampu menunjukkan bahwa karyawan mampu belajar dan mengembangkan dirinya secara efektif. Di sisi lain, karyawan juga memahami alasan mengapa mereka harus mengikuti kegiatan pelatihan dan pengembangan dan apa yang diharapkan organisasi kepada mereka. Wren (1994) menerangkan bahwa para ahli organisasi formal berpendapat bahwa seorang karyawan akan bekerja dengan lebih baik, jika dia mengetahui apa yang diharapkan organisasi darinya. Dalam kondisi tersebut, karyawan kan menjadi lebih terpuaskan dan produktif. 
Selain itu, menurut Garvin (1993) bahwa karyawan juga akan mampu memberikan contoh dari kegiatan pengembangan yang pernah dilakukan, baik dari segi pengetahuan, sikap maupun ketrampilan kepada karyawan lain. Hal ini akan mendukung terciptanya learning organization, yaitu organisasi yang mampu menciptakan dan mencari dan mentransfer pengetahuan dan mengubah perilakunya sesuai dengan pengetahuan barunya. Tentu saja, pengembangan karyawan pendidikan diutamakan yang selaras dengan kualifikasi yang dibutuhkan pekerjaan atau standar eksternal yang sesuai (atau keduanya).

Objek penelitian ini adalah seluruh tenaga kependidikan tetap di FE UII, sebanyak 64 orang. Penelitian ini bertujuan untuk: (1) mengidentifikasi jumlah kebutuhan tenaga kependidikan tetap yang sesuai dengan beban kerja yang ada di FE Ull; (2) mengidentifikasi kesesuaian antara penempatan dengan keinginan dari tenaga kependidikan tetap di FE UII; dan (3) mengidentifikasi program pengembangan tenaga kependidikan tetap di FE UII, untụk mendapatkan kesesuajan antara kompetensi tenaga kependidikan tetap dengan kebutuhan pekerjaan.

Data primer yang meliputi data mengenai apa yang' diinginkan tenaga kependidikan tetap terkait dengan pekerjaannya di FE UII diperoleh dengan menggunakan kuesioner. Sedangkan data sekunder yang meliputi data usia, tingkat pendidikan, pekerjaan dan posisi saat ini serta kualifikasi sumber daya manusia yang dibutuhkan untuk setiap pekerjaan/jabatan, jumlah mahasiswa FE IIII yang aktif di semester ganjil 2011/2012, jumlah tenaga kependidikan kontrak diperoleh melalui dokumen yang ada di FE UII dan studi kepustakaan.

Langkah-langkah analisis dilakukan melalui tahapan: Pertama, menghitung kebutuhan jumlah tenaga kependidikan tetap ideal dengan mempertimbangkan jumlah mahasiswa. Pedoman Pengisian Alat Evaluasi Mutu Internal Perguruan Tinggi Indonesia (Draft Versi 1.1) (2011) menjelaskan bahwa rasio tenaga kependidikan dan mahasiswa $1:<100$. Oleh karena tidak ditetapkan angka yang pasti, maka dalam pemetaan ini mengambil angka yang moderat yaitu 75.

Kedua, mengidentifikasi usia saat ini, selisih usia saat ini dan usia pensiun, pendidikan terakhir riil, pekerjaan dan posisi saat ini dan kelayakan pengembangan terkait pekerjaan saat ini. Tujuan tahap ini untuk mengetahui kondisi tenaga kependidikan saat ini dan menghitung kelayakan program pengembangan dari sisi usianya (lebar sempitnya kesempatan). Sisa usia produktif, dihitung dengan mempertimbangkan: (1) Peraturan Dana Pensiun dari Dana Pensiun Pegawai Universitas Islam Indonesia Bab XIX Pasal 25 Ayat 1, dijelaskan bahwa usia pensiun normal ditetapkan 55 tahun; (2) Surat Keputusan Rektor Nomor 815/SK-Rek/BPSDM/X/2003 Pasal 2 dijelaskan bahwa tenaga kependidikan berhak untuk mengambil masa persiapan pensiun (MPP), selama 1 tahun sebelum pensiun; dan (3) Peraturan Universitas Nomor 15/ PU-Rek/IX/2010 tentang jabatan fngsional, pangkat dan angka kredit pustakawan UII, Pasal 30 ayat 2 yang berbunyi Pustakawan dengan jabatan fungsional pustakawan penyelia atau pustakawan muda dengan pangkat penata, gol/ruang IIIC dengan usia 59 tahun berhak atas MPP dan akan di pensiun pada usia 60 tahun.

Ketiga, menganalisis penempatan yang saat ini ada dan melakukan rotasi jika dibutuhkan. Tahap ini bertujuan mengetahui kesesuaian penempatan dengan kemauan tenaga kependidikan. Jika ada ketidaksesuaian, harus segera diambil tindakan untuk mencegah dampak negatifnya. Keempat, mengidentifikasi target karier (keinginan terkait pekerjaan) dari setiap tenaga kependidikan tetap, kualifikasi yang dibutuhkan untuk pekerjaan/jabatan yang diinginkan dan aktivitas pengembangan yang harus dilakukan untuk mewujudkan target karier tersebut. Tahap ini bertujuan mengetahui target karier (keinginan terkait pekerjaan, karena pada dasarnya jabatan di UII, bukanlah jabatan karier) dan aktivitas pengembangan yang sudah dilakukan oleh tenaga kependidikan tetap sesuai, yang bisa jadi FE UII tidak memiliki 
datanya secara riil. Banyak tenaga kependidikan tetap melakukan pengembangan diri tanpa memberi informasi kepada FE UIII. Alasannya adalah bahwa pengembangan diri dilakukan dengan biaya sendiri.

Langkah terakhir, kelima, menyusun matriks penilaian kebutuhan pelatihan tenaga kependidikan tetap. Pengembangan tenaga kependidikan harus sejalan dengan tujuan organisasi. Matriks ketrampilan membantu untuk meninjau kebutuhan pelatihan pada tingkat individu maupun tim. Jumlah maksimum peserta pelatihan di akhir kolom matriks pada tiap keahlian menunjukkan kebutuhan organisasi. Matriks keterampilan membantu menetapkan pelatihan yang dapat dilakukan secara "on the job", jika ada tenaga kependidikan tetap yang telah memiliki kualifikasi sudah terlatih dan dapat melatih orang lain (ST). Untuk tenaga kependidikan ini, jenis pelatihan yang diutamakan untuk dapat dikuti oleh semua tenaga kependidikan adalah: Pelatihan microsoft office : MS-Word dan Excel, pelatihan ketrampilan manajerial tingkat dasar, service excellent, manajemen kantor dan pengarsipan serta workshop audit mutu.

\section{KINERJA, KEMAMPUAN DAN KEMAUAN KARYAWAN}

Prawirosentono (1999) berpendapat bahwa karyawan dapat dikatakan berprestasi dalam pekerjaan jika mereka dapat melaksanakan pekerjaannya dengan baik, artinya mencapai tujuan kerja yang ditetapkan. Sedangkan Nawawi (2008) mendefinisikan kinerja adalah hasil pelaksanaan suatu pekerjaan, baik bersifat fisik/material maupun no-fisik/non-material. Prawirosentono (1999) menyatakan bahwa kinerja dipengaruhi oleh motivasi karyawan yang bekerja dalam suatu organisasi. Bila karyawan motivasinya rendah, jangan berharap hasil kerja (kinerjanya) baik. Keberhasilan suatu kinerja didasarkan atas efektivitas dan efisiensi, tanggung jawab, disiplin dan inisiatif. Handoko (2011) menerangkan bahwa kepuasan kerja mencerminkan perasaan seseorang terhadap kinerjanya. Karyawan akan merasakan kepuasan terhadap pekerjaannya dan pada akhirnya memotivasi untuk berkinerja tinggi, jika pekerjaan yang dilakukannya adalah pekerjaan yang dia mampu dan mau.

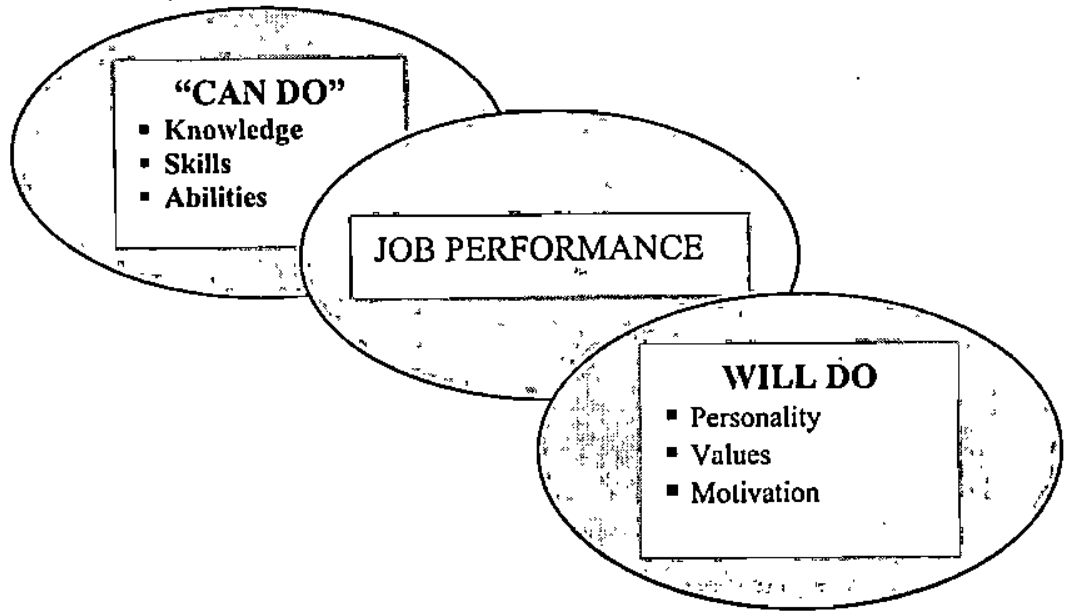

Gambar 1. "Can Do" And "Will Do" Factors in Selection Decisions

Sumber : Bohlander, 2010:288

\section{PENGEMBANGAN KARIER}

Handoko (2011) menjelaskan bahwa suatu karier adalah semua pekerjaan (jabatan) yang dipunyai (atau dipegang) selama kehidupan seseorang. Sikap atasan, pengalaman, pendidikan dan juga "nasib" memainkan peranan penting dalam permasalahan karier ini. Karier harus dikelola melalui suatu perencanaan yang cermat. Bila tidak, karyawan akan sering tidak 
siap memanfaatkan berbagai kesempatan karier dan departemen SDM akan menghadapi kesulitan untuk memenuhi kebutuhan penyusunan personalia (staffing) internal organisasi.

Handoko (2011) berpendapat bahwa titik awal pengembangan karier dimulai dari diri karyawan. Setiap orang bertanggungjawab atas pengembangan atau kemajuan kariernya. Akan tetapi, pengembangan karier seharusnya tidak hanya tergantung pada usaha-usaha individu saja, karena hal itu tidak selalu sesuai dengan kepentingan organisasi. Menurut Handoko (2011), untuk mengarahkan pengembangan karier agar menguntungkan organisasi dan karyawan, departemen SDM dapat mengadakan program-program pelatihan dan pengembangan bagi karyawan.

Bohlander dan Scott (2010) menjelaskan bahwa dalam mengembangkan karyawan untuk mendukung kariernya, departemen SDM harus dapat mensinkronkan antara kebutuhan organisasi (baik secara strategic maupun operasional) dengan kebutuhan karyawan (baik secara professional maupun personal) (Bohlander, 2010).

Menurut Bohlander dan Scott (2010), tahapan-tahapan pengembangan karier dapat dejelaskan sebagai berikut :

1. Preparation For Work (Ages 0 - 25)

Pada tahap ini, yang dilaksanakan adalah membangun image pekerjaan, menganalisis berbagai alternative pekerjaan, mengembangkan pilihan pekerjaan awal, mengikuti pendidikan yang sesuaj dengan kebutuhan.

2. Organizational Entry (Ages 18 - 25)

Pada tahap ini, yang dilaksanakan adalah meraih penawaran kerja dari perusahaan yang diinginkan, memilih pekerjaan yang tepat berdasarkan informasi yang komplit dan akurat.

\section{Early Career (Ages 25-40)}

Pada tahap ini, yang dilakukan adalah setelah mendapatkan pekerjaan di perusahaan yang diinginkan maka yang dilakukan adalah mempelajari pekerjaan dengan baik, memahami aturan dan norma organisasi, menyesuaikan diri dengan pekerjaan dan organisasi di mana bekerja, meningkatkan kompetensi dan berusaha mewujudkan tujuan-tujuan yang telah ditetapkan.

\section{Midcareer (Ages 40-55)}

Pada tahap ini, yang dapat dilakukan adalah menilai ulang target karier dan tujuan-tujuan yang ditetapkan di awal, menegaskan kembali dan memodifikasi kembali tujuan, membuat pilihan yang tepat untuk diri yang berada dalam usia tengah baya dan tetap menjaga produktivitas.

\section{Late Career (Ages 55 - Retirement)}

Pada tahap ini, yang harus dilakukan adalah tetap menjaga produktivitas kerja, memelihara kepercayaan diri dan mempersiapkan diri untuk pensiun yang efektif.

\section{PEMETAAN KARYAWAN}

Dalam sebuah perusahaan SDM yang lazim disebut dengan karyawan dianggap sebagai asset dan sebagai capital yang menentukan. SDM sebagai kapital sering juga disebut dengan Human Capital. Human capital sangat berkaitan dengan input, proses dan output. Pemetaan tenaga kependidikan dalam perspektif human capital pada dasarnya memposisikan SDM berdasarkan suatu ukuran yang tangible, sehingga secara rasional dan logis kita dapat menempatkan SDM sesuai dengan dimensi pengukuran yang dibutuhkan.

Input berkaitan dengan demographi dan populasi. Sedangkan proses berkaitan dengan pendidikan formal dan pelatihan terstruktur yang diikuti. Dalam proses kadang-kadang 
dipertimbangkan pula pengalaman yang berkaitan dengan informal learning. Output berkaitan dengan kualifikasi ketenagakerjaan seperti keahlian, profesionalisme, managerial. Ujung dari output ini adalah kinerja yang diberikan SDM atau karyawan terhadap perusahaan atau organisasinya.

Pemetaan karyawan dalam perspektif human capital bersumbu utama pada kinerja. Kinerja langsung adalah kontribusi langsung yang diperoleh perusahaan dari karyawannya. Namun, ada pula kinerja tidak langsung yang lazim disebut dengan potensi. Persilangan antara kinerja dan potensi akan menghasilkan pemetaan tenaga kependidikan. Dengan asumsi bahwa proses rekrutmen telah dilakukan dengan baik, maka hasil pemetaan tenaga kependidikan akan memberikan masukan yang sangat bermanfaat untuk perbaikan sistem manajemen SDM dan sistem pengelolaan perusahaan.

\section{Pembahasan}

Data untuk pemetaan tenaga kependidikan tetap di FE UII, yaitu sebanyak 64 orang. Berdasarkan hasil perhitungan, idealnya rasio tenaga kependidikan dengan mahasiswa adalah 1:75, sehingga dibutuhkan tenaga kependidikan sejumlah 65 orang. Faktanya, di FE Ull pada periode semester ganjil 2011/2012 hanya memiliki 64 orang tenaga kependidikan tetap, sehingga rasio jumlah tenaga kependidikan tetap dengan mahasiswa 1:77. Rasio ini masih berada pada kategori Ideal.

Sedangkan identifikasi terhadap usia saat ini, selisih usia saat ini dan usia pensiun, rencana pensiun dini, rencana pengambilan MPP dan sisa usia produktif, tergambar pada tabel berikut:

Tabel 1. Identifikasi usia saat ini, selisih usia saat ini dan usia pensiun, rencana pensiun dini, rencana pengambilan MPP dan sisa usia produktif

\begin{tabular}{|c|c|c|c|c|c|}
\hline $\begin{array}{c}\text { NOMOR } \\
\text { RESPONDEN }\end{array}$ & $\begin{array}{c}\text { USIA } \\
\text { SAAT } \\
\text { INI }\end{array}$ & $\begin{array}{c}\text { SELISIH USIA SAAT INI } \\
\text { DENGAN USIA PENSIUN }\end{array}$ & $\begin{array}{c}\text { PENSIUN } \\
\text { DINI }\end{array}$ & MPP & $\begin{array}{c}\text { SISA USIA } \\
\text { PRODUKTIF }\end{array}$ \\
\hline 1 & 46 & 9 & 0 & 0 & 9 \\
\hline 2 & 53 & 7 & 0 & 0 & 7 \\
\hline 3 & 31 & 24 & 0 & 0 & 24 \\
\hline 4 & 49 & 6 & 0 & 0 & 6 \\
\hline 5 & 54 & 6 & 0 & 0 & 7 \\
\hline 6 & 26 & 29 & 0 & 0 & 29 \\
\hline 7 & 49 & 6 & 0 & 0 & 6 \\
\hline 8 & 38 & 17 & 0 & 0 & 17 \\
\hline 9 & 42 & 13 & 1 & 1 & 12 \\
\hline 10 & 48 & 7 & 0 & 0 & 7 \\
\hline 11 & 43 & 12 & 0 & 0 & 12 \\
\hline 12 & 44 & 11 & 0 & 0 & 11 \\
\hline 13 & 54 & 1 & 0 & 0 & 1 \\
\hline 14 & 34 & 21 & 0 & 1 & 20 \\
\hline 15 & 52 & 3 & 0 & 0 & 3 \\
\hline 16 & 28 & 27 & 0 & 0 & 27 \\
\hline 17 & 35 & 20 & 0 & 0 & 20 \\
\hline 18 & 46 & 9 & 0 & 0 & 9 \\
\hline 19 & 40 & 15 & 0 & 0 & 15 \\
\hline 20 & 34 & 21 & 0 & 1 & 20 \\
\hline
\end{tabular}




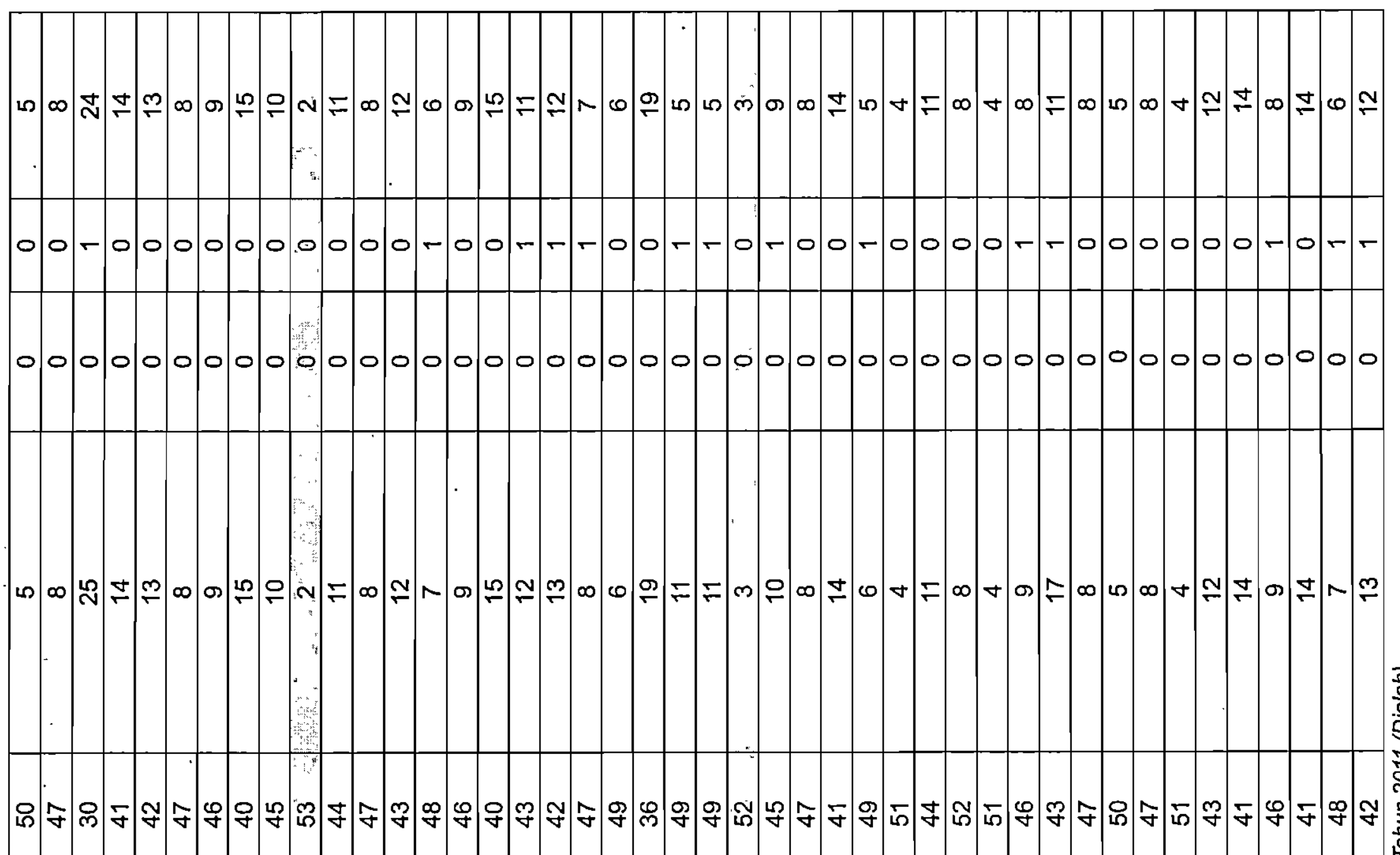

등

品过

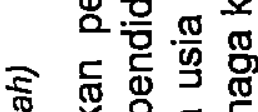

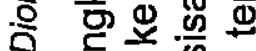

的

동

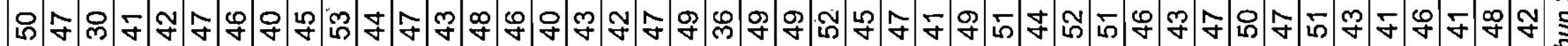

$\Phi$

$\mathbb{E}$

क

疍

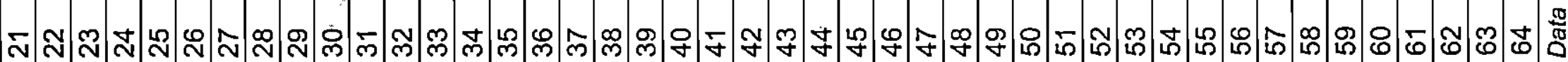

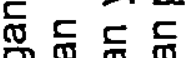

욜

这要 
Tenaga kependidikan yang memiliki sisa usia produktif $<4$ tahun, tinggal dikelola agar produktivitasnya terjaga dan sudah harus mulai dipersiapkan (lahir dan batin) untuk pensiun dengan memberi pelatihan-pelatihan terkait. Tenaga kependidikan yang masuk dalam kriteria ini, tidak lagi diikutkan dalam pemetaan tenga kependidikan untuk mengikuti program pengembangan. Daftar tenaga kependidikan di FE Uli yang memiliki sisa usia produktif $<4$ tahun dapat dilihat pada tabel 2.

Tabel 2.

Daftar Tenaga Kependidikan di FE UII yang memiliki usia produktif $<4$ tahun

\begin{tabular}{|c|c|c|}
\hline NOMOR RESPONDEN & USIA SAAT INI & SISA USIA PRODUKTIF \\
\hline 13 & 54 & 1 \\
\hline 15 & 52 & 3 \\
\hline 30 & 53 & 2 \\
\hline 44 & 52 & 3 \\
\hline
\end{tabular}

Sumber : Data Primer Tahun 2011 (Diolah)

Terdapat 4 (empat) orang tenaga kependidikan di atas akan pensiun paling lama 3 (tiga) tahun yang akan datang. Apabila hal ini terjadi, maka tenaga kependidikan tetap FE UII tinggal berjumlah 60 orang. Hal ini tidak perlu dirisaukan, karena dengan asumsi jumlah mahasiswa aktif di tiga tahun yang akan datang sama dengan tahun 2011, maka rasio tenaga kependidikan dengan mahasiswa 1: 82. Rasio ini masih berada dalam kategori Ideal. Artinya jumlah tenaga kepegawaian yang saat ini berada di FE UII masih dapat dipertahankan minimal sampai dengan 3 tahun kedepan.

Tenaga kependidikan di FE UII yang dapat dikembangkan baik secara horizontal dan atau vertical sebanyak 60 orang. Tabel 3 menununjukkan posisi saat ini dan kesesuaian antara posisi saat ini dengan yang diinginkan tenaga kependidikan yang masih dapat dikembangkan di FE UII. Hal ini harus diketahui oleh organisasi karena individu yang akan memiliki kinerja baik adalah individu yang memiliki kemampuan dan kemauan dalam menjalankan tugas pekerjaannya. Bagi Individu yang menganggap pekerjaannya sekarang tidak sesuai dengan yang diinginkannya, maka tugas organisasi adalah segera merotasinya, sebelum ketidaksukaan atas pekerjaan tersebut berdampak negatif bagi kinerja individu tersebut.

Tabel 3. Kesesuaian antara posisi saat ini dengan keinginan tenaga kependidikan FE UII

\begin{tabular}{|c|c|c|c|c|c|c|}
\hline \multirow{2}{*}{$\begin{array}{c}\text { Nomor } \\
\text { Responden }\end{array}$} & \multicolumn{4}{|c|}{ Pekerjaan Saat Ini } & \multirow{2}{*}{ Posisi Saat Ini } & \multirow{2}{*}{$\begin{array}{c}\text { Kesesuaian } \\
\text { Pekerjaan Saat Ini } \\
\text { Dengan Keinginan }\end{array}$} \\
\hline & Bagian & Urusan & Gol. & Fungsional & & \\
\hline 1 & $\begin{array}{l}\text { Umum \& } \\
\text { Rumah } \\
\text { Tangga } \\
\end{array}$ & Parkir \& Minum & ID & & - & Sesuai \\
\hline 2 & Perpustakaan & Perpustakaan & $\mathrm{IIIC}$ & Pustakawan & $\begin{array}{l}\text { Kepala divisi } \\
\text { Perpustakaan }\end{array}$ & Sesuai \\
\hline 3 & Keuangan & Keuangan & $\mathrm{IIC}$ & & $\begin{array}{l}\text { Koord. } \\
\text { Pembukuan }\end{array}$ & Sesuai \\
\hline 4 & $\begin{array}{l}\text { Umum \& } \\
\text { Rumah } \\
\text { Tangga }\end{array}$ & Parkir \&-Minum & IIA & & - & Sesuai \\
\hline 5 & Perpustakaan & Pelayanan Teknis & IIIC & & - & Sesual \\
\hline 6 & Keuangan & Keuangan & $\| C$ & & - & Sesual \\
\hline 7 & Akademik & Presensi & $\| \mathrm{A}$ & & - & Sesual \\
\hline 8 & SIM & $\mathrm{SIM}$ & IIA & & - & \\
\hline 9 & SDM & Kepegawalan & IID & & $\begin{array}{l}\text { Kepala DIVIsí } \\
\text { SDM }\end{array}$ & Sesual \\
\hline
\end{tabular}


UNISIA, Vol. XXXIII No. 75. Juli 2011

\begin{tabular}{|c|c|c|c|c|c|}
\hline 10 & $\begin{array}{l}\text { Jurusan limu } \\
\text { Ekonomi }\end{array}$ & Staf Adm. & IIB & - & Sesuai \\
\hline 11 & Perpustakaan & Pelayanan Teknis & IID & $\begin{array}{l}\text { Kaur. } \\
\text { Digitalisai } \\
\text { (Lebrary) } \\
\text { Perpustakaan }\end{array}$ & Sesuai \\
\hline 12 & Keuangan & Bendahara & IID & $\begin{array}{l}\text { Kaur Sirkulasi } \\
\text { Keuangan }\end{array}$ & Sesuai \\
\hline 14 & $\begin{array}{l}\text { Rumah } \\
\text { Tangga }\end{array}$ & $\begin{array}{l}\text { (SIAT) Sistem } \\
\text { Informasi Akun. } \\
\text { Terpadu }\end{array}$ & $\| A$ & 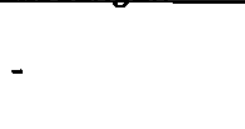 & Sesuai \\
\hline 16 & $\operatorname{SIM}$ & SIM & $\| \mathrm{C}$ & - & Sesuai \\
\hline 17 & $\begin{array}{l}\text { Pasca } \\
\text { Sarjana }\end{array}$ & Sekretaris & IIA & - & Sesuai \\
\hline 18 & Akademik & Presensi & IIA & - & Sesuaj \\
\hline 19 & Akademik & $\begin{array}{l}\text { Administrasi } \\
\text { Akademik }\end{array}$ & IIC & . & Sesuai \\
\hline 20 & SDM & Humas & IIA & - & Sesuai \\
\hline 21 & Akademik & Perkuliahan & IIIA & $\begin{array}{l}\text { Kaur. } \\
\text { Perkulihaan }\end{array}$ & Sesuai \\
\hline 22 & SIM & $\operatorname{SIM}$ & IIIB & Kadiv. SIM & Sesuai \\
\hline 23 & Akademik & Loket & $\| \mathrm{C}$ & - & Sesuai \\
\hline 24 & $\begin{array}{l}\text { Umum \& } \\
\text { Rumah } \\
\text { Tangga } \\
\end{array}$ & Parkir \& Minum & ID & - & Sesuai \\
\hline 25 & Adm. Umum & Ekspedisi & IIA & - & Sesuai \\
\hline 26 & SIM & SIM & $\mathrm{IIB}$ & - & Sesuai \\
\hline 27 & $\begin{array}{l}\text { Adm. } \\
\text { Keuangan }\end{array}$ & Presensi & IIB & - & Sesuai \\
\hline 28 & Humas & Surat Keluar & ID & & Sesuai \\
\hline 29 & $\begin{array}{l}\text { Rumah } \\
\text { Tangga } \\
\end{array}$ & Rumah Tangga & $\mathrm{IIC}$ & & Sesuai \\
\hline 31 & $\begin{array}{l}\text { Umum \& } \\
\text { Rumah } \\
\text { Tangga } \\
\end{array}$ & Parkir \& Minum & IIA & - & Sesuai \\
\hline 32 & Akademik & Presensi & $\| \mathrm{A}$ & - & Sesuai \\
\hline 33 & Akademik & Perkuliahan & ID & & Sesuai \\
\hline 34 & $\begin{array}{l}\text { Umum \& } \\
\text { Rumah } \\
\text { Tangga } \\
\end{array}$ & Parkir \& Minum & IIB & - & Sesuai \\
\hline 35 & $\begin{array}{l}\text { Umum \& } \\
\text { Rumah } \\
\text { Tangga } \\
\end{array}$ & Teknisi & $\| A$ & - & Sesuai \\
\hline 36 & $\begin{array}{l}\text { Pasca } \\
\text { Sarjana }\end{array}$ & Keuangan & $\| \mathrm{A}$ & - & Sesuai \\
\hline 37 & $\begin{array}{l}\text { Kemhs dan } \\
\text { Keagamaan }\end{array}$ & $\begin{array}{l}\text { Kemahasiswaan } \\
\text { dan Agama }\end{array}$ & IIIA & - & Sesuai \\
\hline 38 & SDM & Kepegawaian & IIA & - & Sesuai \\
\hline 39 & Keuangan & Keuangan & IIIB & $\begin{array}{l}\text { Kadiv. } \\
\text { Keuangan }\end{array}$ & Sesuai \\
\hline 40 & $\begin{array}{l}\text { Program } \\
\text { PPAK }\end{array}$ & Program PPAK & $\| A$ & - & Sesuai \\
\hline
\end{tabular}


Pemetaan Tenaga Kependidikan ... (Suhartini)

\begin{tabular}{|c|c|c|c|c|c|c|}
\hline 41 & $\begin{array}{l}\text { Adm } \\
\text { Keuangan }\end{array}$ & Kasir & IID & & . & Sesuai \\
\hline 42 & Perpustakaan & Pelayanan Teknis & IIIC & Pustakawan & - & Sesuai \\
\hline 43 & Perpustakaan & Pengolahan & IIIB & Pustakawan & $\begin{array}{l}\text { Kepala } \\
\text { Urusan } \\
\text { Pelayanan } \\
\text { Teknis( } \\
\text { prosesing) }\end{array}$ & Sesuai \\
\hline 45 & Akademik & Loket & IIIB & & - & Sesuai \\
\hline 46 & Akademik & Perkuliahan & IIA & & & Sesuai \\
\hline 47 & SDM & SDM & IIA & & - & Sesuai \\
\hline 48 & $\begin{array}{l}\text { Umum \& } \\
\text { Rumah } \\
\text { Tangga }\end{array}$ & $\begin{array}{l}\text { Keamanan \& } \\
\text { Kebersihan }\end{array}$ & IIIA & & $\begin{array}{l}\text { Koord. Keam. } \\
\text { \& Kebersihan }\end{array}$ & Sesuai \\
\hline 49 & Akademik & Presensi & IIB & & - & Sesuai \\
\hline 50 & $\begin{array}{l}\text { Rumah } \\
\text { Tangga } \\
\end{array}$ & Keamanan & ID & & & Sesuai \\
\hline 51 & Perpustakaan & Sirkulasi & $\mid \mathrm{IIB}$ & Pustakawan & - & Sesuai \\
\hline 52 & $\begin{array}{l}\text { Jurusan } \\
\text { Akuntansi }\end{array}$ & Staf Adm. & IIIB & & - & Tidak Sesuai \\
\hline 53 & SDM & Tata Usaha & IIIA & & $\begin{array}{l}\text { Kaur tata } \\
\text { Usaha }\end{array}$ & Sesuai \\
\hline 54 & Perpustakaan & Sirkulasi & IilA & Pustakawan & $\begin{array}{l}\text { Kaur. } \\
\text { Pelayanan } \\
\text { Pemakai } \\
\text { (Sirkulasi) } \\
\end{array}$ & Sesuai \\
\hline 55 & $\begin{array}{l}\text { Prodi } \\
\text { Manajemen }\end{array}$ & Prodi Manajemen & IIA & & - & Tidak Sesuai \\
\hline 56 & \begin{tabular}{|l|} 
Pasca \\
Sarjana \\
\end{tabular} & Pascasarjana & IIIB & & - & Sesuai \\
\hline 57 & $\begin{array}{l}\text { Umum \& } \\
\text { Rumah } \\
\text { Tangga } \\
\end{array}$ & $\begin{array}{l}\text { Umum \& Rumah } \\
\text { Tangga }\end{array}$ & IIIA & & - & Sesuai \\
\hline 58 & Perpustakaan & Pelayanan Teknis & IID & & - & Sesuai \\
\hline 59 & Akademik & Presensi & IIA * & & - & Sesuai \\
\hline 60 & \begin{tabular}{|l} 
Pasca \\
Sarjana
\end{tabular} & Keuangan & IIA & & - & Sesuai \\
\hline 61 & Akademik & Akademik & IIIB & & - & Sesuai \\
\hline 62 & \begin{tabular}{|l|} 
Pasca \\
Sarjana \\
\end{tabular} & Akademik & IIA & & - & Sesuai \\
\hline 63 & $\begin{array}{l}\text { Administrasi } \\
\text { Akademik }\end{array}$ & $\begin{array}{l}\text { Administrasi } \\
\text { Akademik }\end{array}$ & IID & & \begin{tabular}{|l|} 
Kepala Divisi \\
Administrasi \\
Akaemik \\
\end{tabular} & Sesuai \\
\hline 64 & Adm. Umum & Tata Usaha & IID & & - & Sesuai \\
\hline
\end{tabular}

Sumber : Data Primer Tahun 2011 (Diolah)

Dari sisi penempatan yang saat ini ada dan melakukan rotasi jika dibutuhkan, Tabel 3 menunjukkan bahwa terdapat 2 (dua) orang tenaga kependidikan yang menyatakan bahwa pekerjaannya saat ini tidak sesuai dengan keinginannya. Berdasarkan kondisi tersebut, pimpinan FE UII dapat memanggil kedua tenaga kependidikan tersebut untuk mendiskusikan 
apa yang diinginkannya, mencocokkan kemampuan dan keinginan tenaga kependidikan dan melakukan rotasi. Apabila hal ini tidak segera ditindaklanjuti, dikhawatirkan akan menimbulkan ketidakpuasan kerja dan pada akhirnya akkan menurunkan kinerja tenaga kependidikan yang bersangkutan.

Hasil identifikasi terhadap target karier (keinginan terkait pekerjaan) dari setiap tenaga kependidikan tetap, kualifikasi yang dibutuhkan untuk pekerjaan/jabatan yang diinginkan dan aktivitas pengembangan yang sudah dilakukan untuk mewujudkan target karier tersebut, menunjukkan bahwa dari 60 orang tenaga kependidikan yang memiliki usia produktif $>$ 4 tahun, hanya 11 orang (18\%) yang secara tegas menyatakan bahwa mereka memiliki target karier atas pekerjaannya saat ini. Hal ini sangat memprihatinkan, walaupun memang sebenarnya, jabatan di UII bukanlah jabatan karier, tetapi "kepasrahan" atau "kepuasan" yang dirasakan tenaga kepegawaian atas pekerjaan yang saat ini diemban, dapat menjadi indikator ketidakinginan tenaga kepegawaian tersebut untuk mengembangkan dirinya. Baik itu meng-up date maupun meng-up grade kemampuan dan ketrampilan yang saat ini dimilikinya. Kondisi ini dapat diatasi dengan dilakukannya pendidikan karier untuk membuka wawasan karyawan, sehingga dapat menginspirasi untuk menetapkan target kerja dan pekerjaan yang lebih tinggi. Artinya, bagaimana memunculkan kebutuhan untuk tumbuh dan berkembang.

Menurut Taylor dalam Wren (1994), pada dasarnya karyawan suka mengendalikan outputnya karena naluri alamiah manusia yang suka mengerjakan hal-hal yang mudah saja. Jadi mengapa susah-susah, jika ada yang mudah. Oleh karenanya, tugas pimpinan untuk mampu menginspirasi (memotivasi)nya untuk mau menetapkan standar capaian atau kinerja atau keinginan yang lebih tinggi.

Di sisi lain, tugas pimpinan dalam hal ini adalah mengakomodasi keinginan tenaga kependidikan yang memiliki kebutuhan untuk menjalankan tugas dengan tanggung jawab yang lebih tinggi tersebut, dengan menyusunkan jalur karier yang harus ditempuh dan program pengembangan yang harus dilakukan. Sedangkan untuk tenaga kependidikan yang tidak memiliki target karier atau sudah puas dengan pekerjaannya sekarang, maka yang dapat dilakukan FE UII adalah memelihara ketrampilan yang dibutuhkan untuk pekerjaan sekarang dengan selalu meng-up date sesuai dengan perkembangan jaman.

Agar tenaga kependidikan tidak méngalami kebosanan, karena pekerjaan yang terlalu terspesialisasi, tetapi juga tidak membutuhkan ketrampilan baru, maka FE UII dapat melakukan: (1) rotasi jabatan, dan (2) perluasan pekerjaan secara horisontal. Rotasi jabatan adalah memindahkan tenaga kependidikan dari suatu pekerjaan ke pekerjaan lain. Pekerjaan- pekerjaan itu sendiri sècara nyata tidakberubah, hanya para tenaga kependidikan yang berputar. Organisasi memperoleh manfaat karena para tenaga kependidikan menjadi cakap dalam beberapa pekerjaan bukan hanya satu pekerjaan. Penguasaan terhadap berbagai macam pekerjaan memberikan kesempatan tumbuh dan membuat tenaga kependidikan merasa lebih bernilai bagi organisasi. Jangka waktu yang tepat untuk melakukan.rotasi pekerjaan sebaiknya 2-3 tahun.

Sedangkan perluasan pekerjaan secara horisontal merupakan penambahan lebih banyak tugas kepada tenaga kependidikan untuk meningkatkan variasi pekerjaan dan mengurangi sifat pekerjaan yang membosankan. Program ini tidak membutuhkan ketrampilan baru, tetapi ada kemungkinan kehilangan sedikit efisiensi, tetapi akan membuat tenaga kependidikan lebih terpuaskan dan termotivasi secara efektif. 
Tabel 4. Identifikasi target karier, kualifikasi yang dibutuhkan untuk pekerjaan/jabatan yang diinginkan dan aktivitas pengembangan yang sudah dilakukan untuk mewujudkan target karier tersebut.

\begin{tabular}{|c|c|c|c|c|c|c|}
\hline $\begin{array}{c}\text { NO } \\
\text { RESPONDEN }\end{array}$ & $\begin{array}{l}\text { PEND. } \\
\text { TERAKHIR } \\
\text { RIIL. }\end{array}$ & $\underset{\text { PNI }}{\text { POSISI SAAT }}$ & $\begin{array}{l}\text { TARGET } \\
\text { KARIER }\end{array}$ & $\begin{array}{c}\text { KUALIFIKAS! } \\
\text { YANG } \\
\text { DIBUTUHKAN } \\
\text { UNTUK } \\
\text { PEKERJAANI } \\
\text { JABATAN } \\
\text { YANG } \\
\text { DIINGINKAN }\end{array}$ & $\begin{array}{c}\text { AKTIVITAS } \\
\text { PENGEMBANGAN } \\
\text { YANG SUDAH } \\
\text { DILAKSANAKAN } \\
\text { UNTUK } \\
\text { MEWUJUDKAN } \\
\text { TARGET KARIER }\end{array}$ & $\begin{array}{l}\text { PROGRAM } \\
\text { PENGEMBANGAN } \\
\text { YANG HARUS } \\
\text { DILAKUKAN } \\
\end{array}$ \\
\hline 1 & SD & 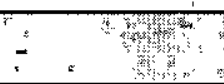 & $\begin{array}{l}\text { Pekerjaan } \\
\text { Saat ini }\end{array}$ & Wy & (4) & , \\
\hline 2 & SMA & $\begin{array}{l}\text { Kepala divisi } \\
\text { Perpustakaan }\end{array}$ & $\begin{array}{l}\text { Pekerjaan } \\
\text { Saat ini }\end{array}$ & & $\therefore$ & $\vdots$ \\
\hline 3 & D3 & $\begin{array}{l}\text { Koord. } \\
\text { Pembukuan }\end{array}$ & $\begin{array}{l}\text { Kadiv } \\
\text { Keuangan }\end{array}$ & $\begin{array}{l}\text { Min SMU, } \\
\text { Min Gol lic, } \\
\text { Menguasai } \\
\text { program } \\
\text { Microsoft } \\
\text { Office, } \\
\text { Sertifikasi SAP } \\
\text { Keuangan, } \\
\text { ketrampilan } \\
\text { Manaierial }\end{array}$ & $\begin{array}{l}\text { D3-akuntansi, } \\
\text { Pelatihan Sisfoin, } \\
\text { SAP FICO \& } \\
\text { SIMKeu \& SIMKeu } \\
\text { Bank }\end{array}$ & $\begin{array}{l}\text { Pelatihan } \\
\text { Manajerial } \\
\text { (Lengkap): } \\
\text { Kepemimpinan; } \\
\text { tim kerja; } \\
\text { Interpersonal Skill } \\
\text { dan Pengambilan } \\
\text { Keputusan }\end{array}$ \\
\hline 4 & MAN & $=\cdots \quad \ldots$ & $\begin{array}{l}\text { Pekerjaan } \\
\text { Saat ini }\end{array}$ & 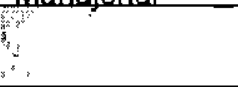 & , & \\
\hline 5 & sma & $\because$ & $\begin{array}{l}\text { Pekerjaan } \\
\text { Saat ini }\end{array}$ & & & \\
\hline 6 & S1 & $n=$ & $\begin{array}{l}\text { Kadiv } \\
\text { Keuangan }\end{array}$ & $\begin{array}{l}\text { Min SMU, } \\
\text { Min Gol IIC, } \\
\text { Menguasai } \\
\text { program, } \\
\text { Microsoft } \\
\text { Office, } \\
\text { Sertifikasi SAP } \\
\text { Keuangan, } \\
\text { ketrampilan } \\
\text { Manajerial } \\
\end{array}$ & $\begin{array}{l}\text { S1, Menguasai } \\
\text { Microsoft Office }\end{array}$ & $\begin{array}{l}\text { Pelatihan Sistoin, } \\
\text { SAP FICO \& } \\
\text { SIMKeu \& SIMKeu } \\
\text { Bank, Pelatihan } \\
\text { Manajerial } \\
\text { (Lengkap): } \\
\text { Kepemimpinan; } \\
\text { tim kerja; } \\
\text { Interpersonal Skill } \\
\text { dan Pengambilan } \\
\text { Keputusan }\end{array}$ \\
\hline 7 & MAN & $\because \quad z^{2}$ & $\begin{array}{l}\text { Pekerjaan } \\
\text { Saat ini }\end{array}$ & 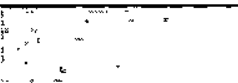 & $\cdots$ & $\therefore$ \\
\hline 8 & D3 & $=x$ & $\begin{array}{l}\text { Pekerjaan } \\
\text { Saat ini }\end{array}$ & & & 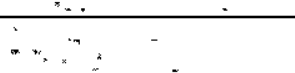 \\
\hline 9 & D3 & $\begin{array}{l}\text { Kepala Divisi } \\
\text { SDM }\end{array}$ & $\begin{array}{l}\text { Pekerjaan } \\
\text { Saat ini }\end{array}$ & $x=$ & : & 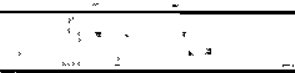 \\
\hline 10 & SMA & $\because-$ & $\begin{array}{l}\text { Pekejuaan } \\
\text { Saat ini }\end{array}$ & $n=\because$ & 4 & 16 \\
\hline 11 & D3 & $\begin{array}{l}\text { Kaur. } \\
\text { Digitalisai } \\
\text { (Lebrary) } \\
\text { Perpustakaan }\end{array}$ & $\begin{array}{l}\text { Kadiv } \\
\text { Perpustakaan }\end{array}$ & $\begin{array}{l}\text { Min SMU, } \\
\text { Min Gol lí, } \\
\text { Menguasai } \\
\text { program } \\
\text { Microsoft } \\
\text { Office, } \\
\text { Menguasai } \\
\text { proses olah } \\
\text { pustaka, } \\
\text { digitalisasi } \\
\text { pustaka, } \\
\text { SIMPus, } \\
\text { ketrampilan } \\
\text { Manajerial }\end{array}$ & $\begin{array}{l}\text { D2-Perpustakaan, } \\
\text { Menguasai } \\
\text { digitalisasi pustaka } \\
\text { dan olah pustaka }\end{array}$ & $\begin{array}{l}\text { Pelatihan } \\
\text { Manajerial } \\
\text { (Lengkap) : } \\
\text { Kepemimpinan; } \\
\text { tim kerja; } \\
\text { Interpersonal Skill } \\
\text { dan Pengambilan } \\
\text { Keputusan }\end{array}$ \\
\hline 12 & D3 & $\begin{array}{l}\text { Kaur Sirkulasi } \\
\text { Keuangan }\end{array}$ & $\begin{array}{l}\text { Pekerjaan } \\
\text { Saat ini }\end{array}$ & 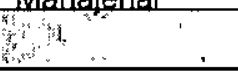 & 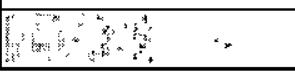 & 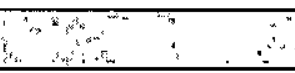 \\
\hline
\end{tabular}




\begin{tabular}{|c|c|c|c|c|c|c|}
\hline 14 & SMA & 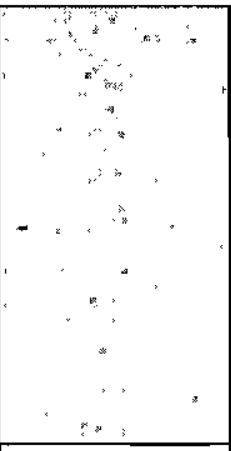 & $\begin{array}{l}\text { Kaur } \\
\text { Perbekalan } \\
\text { dan } \\
\text { Pengolahan } \\
\text { Data } \\
\text { Inventarisasi }\end{array}$ & $\begin{array}{l}\text { Min SMU, } \\
\text { Min Gol IIC, } \\
\text { Menguasai } \\
\text { program } \\
\text { Microsoft } \\
\text { Office, } \\
\text { Menguasai } \\
\text { SIMFOIN, } \\
\text { proses } \\
\text { pengadaan } \\
\text { barang } \\
\text { ketrampilan } \\
\text { Manajerial } \\
\end{array}$ & $\begin{array}{l}\text { Mengambil } \\
\text { Program D3 } \\
\text { Administrasi, } \\
\text { Menguasai } \\
\text { Microsoft Office }\end{array}$ & $\begin{array}{l}\text { Pelatihan } \\
\text { SIMFOIN, } \\
\text { Sertifikasi } \\
\text { Pengadaan } \\
\text { Barang/jasa, } \\
\text { Pelatihan } \\
\text { Manajerial } \\
\text { (Lengkap) }\end{array}$ \\
\hline 16 & S1 & 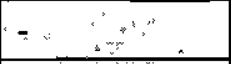 & $\begin{array}{l}\text { Pekerjaan } \\
\text { Saat ini }\end{array}$ & & & $\because:$ \\
\hline 17 & D3 & 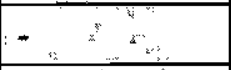 & $\begin{array}{l}\text { Pekerjaan } \\
\text { Saat ini }\end{array}$ & $\therefore$ & $\therefore$ & $a^{3 x}$ \\
\hline 18 & SLTA & 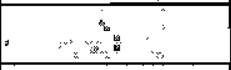 & $\begin{array}{l}\text { Pekerjaan } \\
\text { Saat ini }\end{array}$ & 8 & $\%$ & an: \\
\hline 19 & SMP & - & $\begin{array}{l}\text { Pekerjaan } \\
\text { Saat ini }\end{array}$ & & 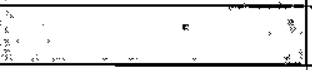 & : \\
\hline 20 & D3 & 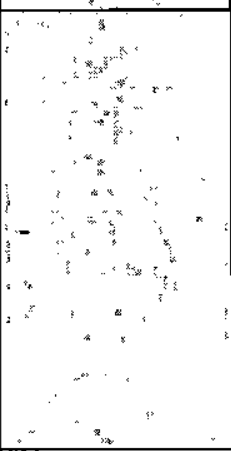 & $\begin{array}{l}\text { Kaur TU \& } \\
\text { Humas }\end{array}$ & $\begin{array}{l}\text { Min SMU, } \\
\text { Min Gol IIC, } \\
\text { Menguasai } \\
\text { program } \\
\text { Microsoft } \\
\text { Office, } \\
\text { Menguasai } \\
\text { ketrampilan } \\
\text { pengarsipan, } \\
\text { ketrampilan } \\
\text { kehumasan } \\
\text { dan ketrampilan } \\
\text { Manaierial } \\
\end{array}$ & $\begin{array}{l}\text { S1, Menguasai } \\
\text { program Microsoft } \\
\text { Office, pelatihan } \\
\text { kehumasan }\end{array}$ & $\begin{array}{l}\text { Pelatihan } \\
\text { Manajemen Kantor } \\
\text { dan Pengarsipan } \\
\text { dan Pelatihan } \\
\text { Manajerial } \\
\text { (Lengkap): } \\
\text { Kepemimpinan; } \\
\text { tim kerja; } \\
\text { Interpersonal Skill } \\
\text { dan Pengambilan } \\
\text { Keputusan }\end{array}$ \\
\hline 21 & SPBMA & $\begin{array}{l}\text { Kaur. } \\
\text { Perkulihaan }\end{array}$ & $\begin{array}{l}\text { Pekerjaan } \\
\text { Saatini }\end{array}$ & $\therefore$ & 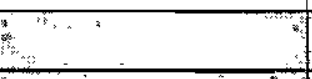 & 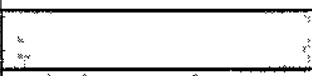 \\
\hline 22 & SMA & Kadiv. SIM & $\begin{array}{l}\text { Pekerjaan } \\
\text { Saatini }\end{array}$ & का & 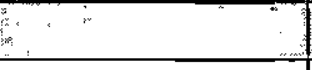 & 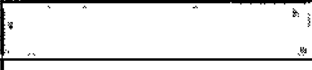 \\
\hline 23 & D3 & 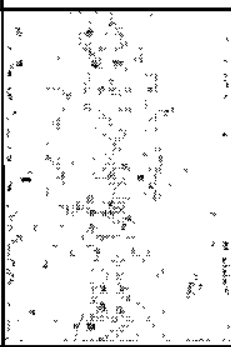 & $\begin{array}{l}\text { Kaur Ujian/ } \\
\text { TU; Kadiv } \\
\text { Adm Akd/ } \\
\text { RT/SDM/ } \\
\text { Perpustakaan }\end{array}$ & $\begin{array}{l}\text { Min SMU, } \\
\text { Min Gol lic, } \\
\text { Menguasai } \\
\text { program } \\
\text { Microsoft } \\
\text { Office, } \\
\text { Menguasai } \\
\text { SIMAK, } \\
\text { ketrampilan } \\
\text { Manajerial } \\
\end{array}$ & $\begin{array}{l}\text { D3 dan Menguasai } \\
\text { program Microsoft } \\
\text { Office }\end{array}$ & $\begin{array}{l}\text { Pelatihan SIMAK } \\
\text { dan Pelatihan } \\
\text { Manajerial } \\
\text { (Lengkap) : } \\
\text { Kepemimpinan; } \\
\text { tim kerja; } \\
\text { Interpersonal Skill } \\
\text { dan Pengambilan } \\
\text { Keputusan } \\
\end{array}$ \\
\hline 24 & $\mathrm{SD}$ & 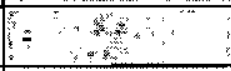 & $\begin{array}{l}\text { Pekerjaan } \\
\text { Saat ini }\end{array}$ & $.^{3}+2$ & sin & $\because \therefore$ \\
\hline 25 & MAN & m- & $\begin{array}{l}\text { Pekerjaan } \\
\text { Saat ini }\end{array}$ & $\therefore \quad: \quad$ & 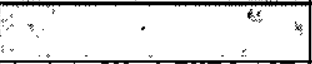 & $\cdots$ \\
\hline 26 & s1 & 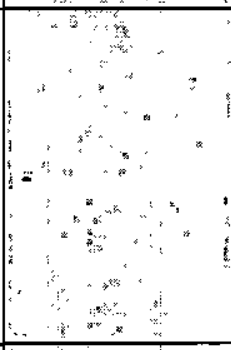 & $\begin{array}{l}\text { Kadiv SIM/ } \\
\text { Akademik }\end{array}$ & $\begin{array}{l}\text { Min SMU, } \\
\text { Min Gol IIC, } \\
\text { Menguasai } \\
\text { program } \\
\text { Microsoft } \\
\text { Office, } \\
\text { Menguasai } \\
\text { SIMAK, } \\
\text { ketrampilan } \\
\text { Manajerial } \\
\end{array}$ & $\begin{array}{l}\text { S1, Menguasai } \\
\text { program Microsoft } \\
\text { Office, SIMAK } \\
\text { dan SIM pada } \\
\text { Umumnya }\end{array}$ & $\begin{array}{l}\text { Pelatihan } \\
\text { Manajerial } \\
\text { (Lengkap) : } \\
\text { Kepemimpinan; } \\
\text { tim kerja; } \\
\text { Interpersonal Skill } \\
\text { dan Pengambilan } \\
\text { Keputusan }\end{array}$ \\
\hline 27 & SMP & 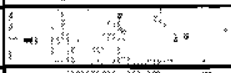 & $\begin{array}{l}\text { Pekerjaan } \\
\text { Saat inj }\end{array}$ & 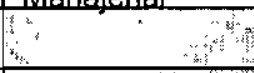 & $x^{2}$ & 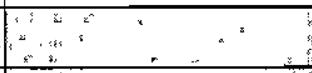 \\
\hline 28 & SMP & 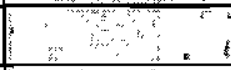 & $\begin{array}{l}\text { Pekerjaan } \\
\text { Saat ini }\end{array}$ & 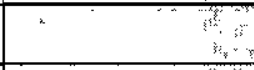 & 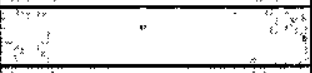 & $1, \mathrm{x}^{n}$ \\
\hline 29 & SLTA & : & $\begin{array}{l}\text { Pekerjaan } \\
\text { Saatini }\end{array}$ & 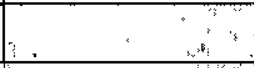 & $\therefore$ & $\because \cdots$ \\
\hline 31 & SD & - & $\begin{array}{l}\text { Pekerjaan } \\
\text { Saatini }\end{array}$ & $\because n \quad 1 \pi$ & 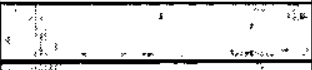 & 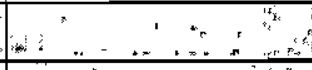 \\
\hline 32 & SMP & {$\left[\begin{array}{lll}5 & 1\end{array}\right.$} & $\begin{array}{l}\text { Pekerjaan } \\
\text { Satin }\end{array}$ & $\therefore$ & 3 & $\begin{array}{r}x^{2} \\
0\end{array}$ \\
\hline 33 & SLTA & 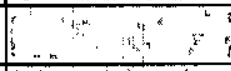 & $\begin{array}{l}\text { Pekerjaán } \\
\text { Sapt ini }\end{array}$ & ing & 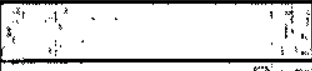 & 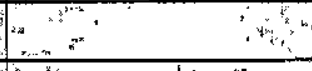 \\
\hline 34 & SMA & 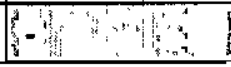 & $\begin{array}{l}\text { Pekerjaan } \\
\text { Saatinl }\end{array}$ & S? & $\int_{21}=$ & 4 \\
\hline
\end{tabular}


Pemetaan Tenaga Kependidikan ... (Suhartini)

\begin{tabular}{|c|c|c|c|c|c|c|}
\hline 35 & $\mathrm{SD}$ & 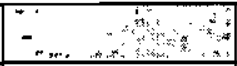 & $\begin{array}{l}\text { Pekerjaan } \\
\text { Saatini }\end{array}$ & 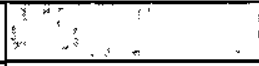 & . & 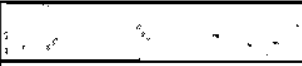 \\
\hline 36 & D3 & $-{ }^{2}+c^{3}$ & $\begin{array}{l}\text { Pekerjaan } \\
\text { Saatini }\end{array}$ & 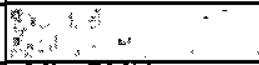 & when & 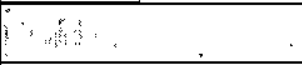 \\
\hline 37 & s1 & 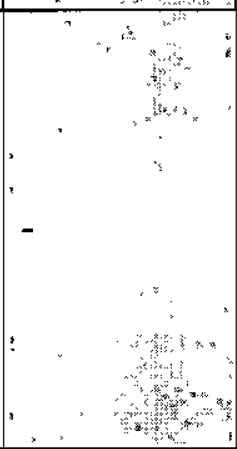 & $\begin{array}{l}\text { Kadiv } \\
\text { Keuangan / } \\
\text { Umum }\end{array}$ & $\begin{array}{l}\text { Min SMU, } \\
\text { Min Gol IIC, } \\
\text { Menguasai } \\
\text { program } \\
\text { Microsoft } \\
\text { Office, } \\
\text { Menguasai } \\
\text { Manajemen } \\
\text { Perkantoran } \\
\text { dan } \\
\text { Pengarsipan } \\
\text { dan ketrampilan } \\
\text { Manaierial }\end{array}$ & $\begin{array}{l}\text { S1 dan Menguasai } \\
\text { program Microsoft } \\
\text { Office }\end{array}$ & $\begin{array}{l}\text { Pelatihan } \\
\text { Manajemen } \\
\text { Perkantoran dan } \\
\text { Pengarsipan } \\
\text { serta Pelatihan } \\
\text { Manajerial } \\
\text { (Lengkap): } \\
\text { Kepemimpinan; } \\
\text { tim kerja; } \\
\text { Interpersonal Skill } \\
\text { dan Pengambilan } \\
\text { Keputusan }\end{array}$ \\
\hline 38 & STM & 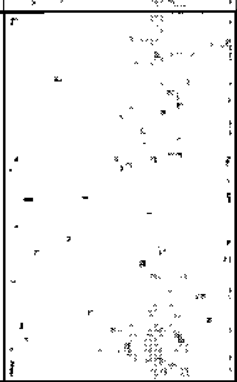 & Kaur TU & $\begin{array}{l}\text { Min Gol IIC, } \\
\text { Menguasai } \\
\text { program } \\
\text { Microsoft } \\
\text { Office, } \\
\text { Menguasai } \\
\text { ketrampilan } \\
\text { pengarsipan } \\
\text { dan ketrampilan } \\
\text { Manaierial }\end{array}$ & $\begin{array}{l}\text { SMU, Menguasai } \\
\text { program Microsoft } \\
\text { Office }\end{array}$ & $\begin{array}{l}\text { Pelatihan } \\
\text { Manajemen Kantor } \\
\text { dan Pengarsipan } \\
\text { dan Pelatihan } \\
\text { Manajerial } \\
\text { (Lengkap): } \\
\text { Kepemimpinan; } \\
\text { tim kerja; } \\
\text { Interpersonal Skill } \\
\text { dan Pengambilan } \\
\text { Keputusan }\end{array}$ \\
\hline 39 & SMEA & $\begin{array}{l}\text { Kadiv. } \\
\text { Keuanoan }\end{array}$ & $\begin{array}{l}\text { Pekerjaan } \\
\text { Saatini }\end{array}$ & t. & Hen & by \\
\hline 40 & SMEA & 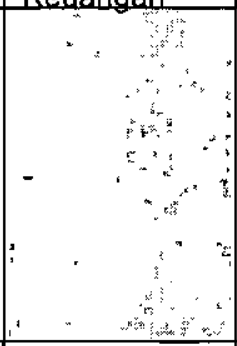 & $\begin{array}{l}\text { Kaur/Kadiv } \\
\text { Akademik }\end{array}$ & $\begin{array}{l}\text { Min SMU, } \\
\text { Min Gol IIC, } \\
\text { Menguasai } \\
\text { program } \\
\text { Microsoft } \\
\text { Office, } \\
\text { Menguasai } \\
\text { SIMAK, } \\
\text { ketrampilan } \\
\text { Manajerial } \\
\end{array}$ & $\begin{array}{l}\text { SMU dan } \\
\text { Menguasai } \\
\text { program Microsoft } \\
\text { Office }\end{array}$ & $\begin{array}{l}\text { Pelatihan SIMAK } \\
\text { dan Pelatihan } \\
\text { Manajerial } \\
\text { (Lengkap) : } \\
\text { Kepemimpinan; } \\
\text { tim kerja; } \\
\text { Interpersonal Skill } \\
\text { dan Pengambilan } \\
\text { Keputusan } \\
\end{array}$ \\
\hline 41 & D3 & $\because \quad 4$ & $\begin{array}{l}\text { Pekerjaan } \\
\text { Saat ini }\end{array}$ & , & in & $=x$ \\
\hline 42 & SMEA & 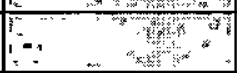 & $\begin{array}{l}\text { Pekerjaan } \\
\text { Saatini }\end{array}$ & 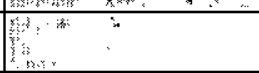 & 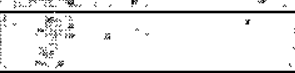 & $x_{n+2}$ \\
\hline 43 & SMEA & $\begin{array}{l}\text { Kepala } \\
\text { Urusan } \\
\text { Pelayanan } \\
\text { Teknis( } \\
\text { prosesing) } \\
\end{array}$ & $\begin{array}{l}\text { Pekerjaan } \\
\text { Saat ini }\end{array}$ & 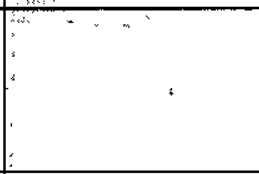 & 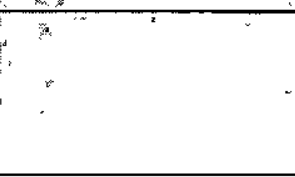 & . \\
\hline 45 & SMA & $=\ldots$ & $\begin{array}{l}\text { Pekerjaan } \\
\text { Saat ini }\end{array}$ & $\because$ & & \\
\hline 46 & SMA & $-1 \cdots$ & $\begin{array}{l}\text { Pekerjaan } \\
\text { Saat ini }\end{array}$ & .6 & $\therefore$ & 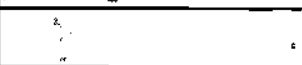 \\
\hline 47 & SMEA & $\sqrt{19} \mathrm{~s}^{2}$ & $\begin{array}{l}\text { Pekejuan } \\
\text { Saat ini }\end{array}$ & क & 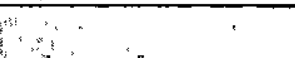 & 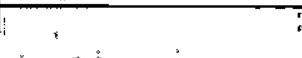 \\
\hline 48 & SMP & 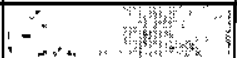 & Pekerjaan & 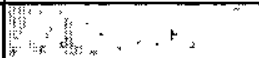 & in & this \\
\hline 49 & SMA & $\begin{array}{l}\text { Koord. Keam. } \\
\text { \& Kebersihan }\end{array}$ & $\begin{array}{l}\text { Pekerjaan } \\
\text { Saat ini }\end{array}$ & $y^{4}$ & 政 & $\cdots$ \\
\hline 50 & SLTA & $x, 4$ & $\begin{array}{l}\text { Pekerjaan } \\
\text { Saat ini }\end{array}$ & $\therefore$ & : & 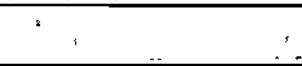 \\
\hline 51 & SMEA & $\because$ & Pekerjaan & : & & $\ldots$ \\
\hline 52 & SMA & 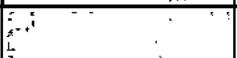 & Pekerjaan & 8 & . & ? \\
\hline 53 & SMA & $\begin{array}{l}\text { Kaur tata } \\
\text { Usaha }\end{array}$ & $\begin{array}{l}\text { Pekerjaañ } \\
\text { Saat inj }\end{array}$ & 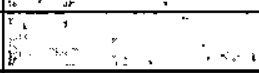 & $y_{1}$ & $\therefore$ \\
\hline 54 & S1 & $\begin{array}{l}\text { Raur. } \\
\text { Pelayanan } \\
\text { Pemakai } \\
\text { (Sirkulasi) } \\
\end{array}$ & $\begin{array}{l}\text { Pekerjaan } \\
\text { Saat ini }\end{array}$ & 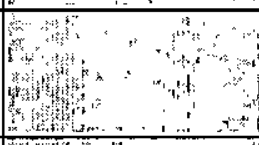 & 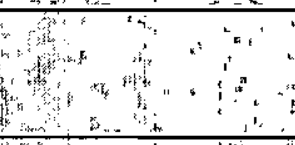 & 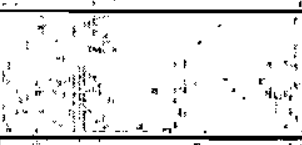 \\
\hline 55 & SMP & 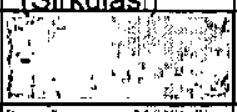 & $\begin{array}{l}\text { Tingkat } \\
\text { Pekerjaan } \\
\text { Saatinl }\end{array}$ & 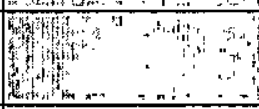 & 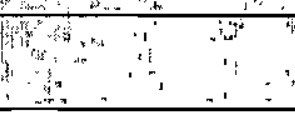 & 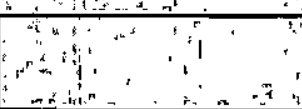 \\
\hline 56 & S1 & 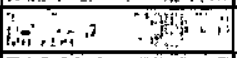 & & 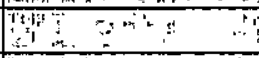 & 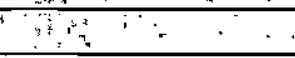 & 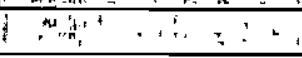 \\
\hline 57 & SMEA & 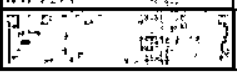 & $\begin{array}{l}\text { Pekerjaan } \\
\text { Saatind }\end{array}$ & $y_{n}-\varepsilon^{\prime \prime}$ & $\pi^{t}, x^{2}$ & $\begin{array}{l}\therefore \\
r_{1}\end{array} \quad \therefore$ \\
\hline
\end{tabular}


UNISIA, Vol. XXXIII No. 75 Juli 2011

\begin{tabular}{|c|c|c|c|c|c|c|}
\hline 58 & SMA & $-\because \ldots$ & $\begin{array}{l}\text { Pekerjaan } \\
\text { Saat ini }\end{array}$ & : & $\because$ & \\
\hline 59 & STM & $\begin{array}{l}-\quad 3 \\
\end{array}$ & $\begin{array}{l}\text { Pekerjaan } \\
\text { Saatini }\end{array}$ & $x:$ & $\therefore$ & \\
\hline 60 & D2 & 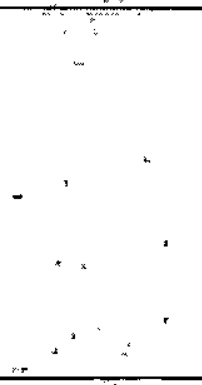 & Kadiv & $\begin{array}{l}\text { Min SMU, } \\
\text { Min Gol IIC, } \\
\text { Menguasai } \\
\text { program } \\
\text { Microsoft } \\
\text { Office, } \\
\text { Sertifikasi SAP } \\
\text { Keuangan, } \\
\text { ketrampilan } \\
\text { Manajerial } \\
\end{array}$ & $\begin{array}{l}\text { D2, Menguasai } \\
\text { Microsoft Office }\end{array}$ & $\begin{array}{l}\text { Pelatinañ Sisfoin, } \\
\text { SAP FICO \& } \\
\text { SIMKeu \& SIMKeu } \\
\text { Bank, Pelatihan } \\
\text { Manajerial } \\
\text { (Lengkap) : } \\
\text { Kepemimpinan; } \\
\text { tim kerja; } \\
\text { Interpersonal Skill } \\
\text { dan Pengambilan } \\
\text { Keputusan }\end{array}$ \\
\hline 61 & SMEA & 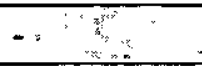 & $\begin{array}{l}\text { Pekerjaan } \\
\text { Saatini }\end{array}$ & & $\because x$ & 5 \\
\hline 62 & SMA & $-\ldots$ & & & $\because$ & $\therefore$ \\
\hline 63 & S1 & $\begin{array}{l}\text { Kepala Divisí } \\
\text { Administrasi } \\
\text { Akaemik }\end{array}$ & $\begin{array}{l}\text { Pekerjaan } \\
\text { Saat ini }\end{array}$ & & 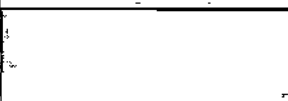 & \\
\hline 64 & SMA & $=\ldots$ & $\begin{array}{l}\text { Pekerjaan } \\
\text { Saatini }\end{array}$ & & & \\
\hline
\end{tabular}

Sumber : Data Primer Tahun 2011 (Diolah)

Dari sisi Penilaian Kebutuhan Pelatihan Tenaga Kependidikan Tetap, dengan tetap mempertimbangkan adanya keterbatasan dan kevalidan data, di mana tenaga kependidikan tidak memberikan informasi secara jelas dan lengkap, maka dapat dibuat matrik penilaian kebutuhan pelatihan. Matrik ini menjelaskan mengenai pengembangan diri apa yang harus dilaksanakan oleh tenaga kependidikan untuk memuaskan kemauannya maupun kebutuhan pekerjaan.

Tabel 5.

Matriks Penilaian Kebutuhan Pelatihan Tenaga Kependidikan Tetap FE U!II

\begin{tabular}{|c|c|c|c|c|c|c|c|c|c|c|c|c|c|c|c|c|c|c|}
\hline $\begin{array}{c}\text { NOMOR } \\
\text { RESPONDEN }\end{array}$ & 1 & 2 & 3 & 4 & 5 & 6 & 7 & 8 & 9 & 10 & 11 & 12 & 13 & 14 & 15 & 16 & 17 & 18 \\
\hline 1 & & & & 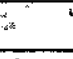 & • & - & & & & & : " & i. & $\mathrm{B}$ & & $B$ & &. & \\
\hline 2 & & & & 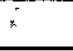 & & & $\mathrm{B}$ & & $B$ & $B$ & & $\mathrm{~B}$ & $B$ & & $\mathrm{B}$ & - & & $B$ \\
\hline 3 & $\mathrm{~B}$ & & B & & & $B$ & & & $B$ & & & $\mathrm{~B}$ & $B$ & & $B$ & & & $B$ \\
\hline 4 & & & & & & & & & & & & & $B$ & $B$ & $B$ & & & \\
\hline 5 & & & & & & & & & & & & & $\mathrm{~B}$ & & $B$ & & & $B$ \\
\hline 6 & & & $B$ & & 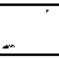 & $B$ & 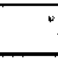 & & $\mathrm{B}$ & & 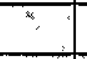 & $B$ & $\mathrm{~B}$ & $B$ & $\mathrm{~B}$ & & & $B$ \\
\hline 7 & & & 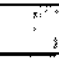 & 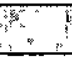 & & & $\therefore$ & & & & $\therefore$ & 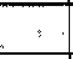 & $\mathrm{B}$ & $\mathrm{B}$ & $\mathrm{B}$ & $\therefore$ & & \\
\hline 8 & & & $\because$ & ST & & & & & $\mathrm{B}$ & 1 & & $B$ & $B$ & ST & $\mathrm{B}$ & & ST & $B$ \\
\hline 9 & & & & & & & & & $B$ & & & $B$ & $\mathrm{~B}$ & & $\mathrm{~B}$ & & & $\mathrm{~B}$ \\
\hline 10 & & & & $B$ & & & B & & $B$ & & & & $B$ & $B$ & $B$ & & & $B$ \\
\hline 11 & $\mathrm{~B}$ & & & $\therefore$ & & & $B$ & & $B$ & $\mathrm{~B}$ & & $\mathrm{~B}$ & $B$ & & $\mathrm{~B}$ & & $\mathrm{~B}$ & $B$ \\
\hline 12 & & & $B$ & & & $\mathrm{~B}$ & & & $\mathrm{~B}$ & & $B$ & & B & & $B$ & & & $\mathrm{~B}$ \\
\hline 14 & $B$ & & & & $\mathrm{~B}$ & $\therefore$ & & & $B$ & & $B$ & $\mathrm{~B}$ & $\mathrm{~B}$ & $\mathrm{~B}$ & $\mathrm{~B}$ & & & $\mathrm{~B}$ \\
\hline 16 & & & & $B$ & & & & & $B$ & & 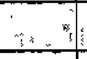 & & $B$ & & $\mathrm{~B}$ & & $\mathrm{~B}$ & $\mathrm{~B}$ \\
\hline 17 & & & & & & & 4 & $B_{1}$ & $\mathrm{~B}$ & 5 & $\therefore$ & . & $B$ & & $\mathrm{~B}$ & $B$ & $\mathrm{~B}$ & $\mathrm{~B}$ \\
\hline 18 & 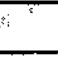 & & & $\mathrm{B}$ & : & & 48 & $\therefore$ & $\mathrm{B}$ & & $: 3$ & $\%$ & $B$ & $\mathrm{~B}$ & $\mathrm{~B}$ & 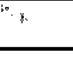 & & $\mathrm{B}$ \\
\hline 19 & & & 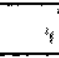 & 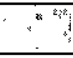 & & & $\because$ & 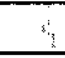 & & 3 & 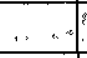 & & $B$ & $B$ & $\mathrm{~B}$ & 8 & & $\mathrm{~B}$ \\
\hline 20 & & & & $\therefore$ & & $\therefore:$ & & $\mathrm{B}$ & $B$ & & 21,6 & $B$ & $B$ & & $\mathrm{~B}$ & $B$ & $\mathrm{~B}$ & $\mathrm{~B}$ \\
\hline 21 & & & & $B$ & 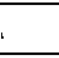 & $\therefore$ & & $1:$ & $\mathrm{B}$ & & $\therefore$ & $B$ & $B$ & & $\mathrm{~B}$ & $1 \quad$ & & $B$ \\
\hline 22 & $F^{2}$ & & & $B$ & & & & & $\mathrm{~B}$ & & $\begin{array}{l}\vdots \cdots \\
\vdots\end{array}$ & $B$ & $B$ & $\therefore$ & $\mathrm{B}$ & & $\mathrm{B}$ & B \\
\hline
\end{tabular}


Pemetaan Tenaga Kependidikan ... (Suhartini)

\begin{tabular}{|c|c|c|c|c|c|c|c|c|c|c|c|c|c|c|c|c|c|c|}
\hline 23 & $B$ & & & $B$ & $\mathrm{~B}$ & & $2 \%$ & \% & $\mathrm{B}$ & & . & $B$ & $\mathrm{~B}$ & & $B$ & ras & $B$ & $\mathrm{~B}$ \\
\hline 24 & 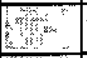 & & . & (") & $n_{\infty}$ & $\because$ & $\begin{array}{ll}3 \\
3\end{array}$ & 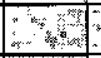 & 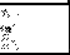 & $v_{3}$ & & vons & $B$ & & $B$ & 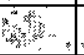 & & ${ }^{*}$ \\
\hline 25 & 4 & & $z^{\prime}$ & 3 & 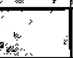 & & & $x^{2}$ & B & & & $8 x$ & $B$ & $\mathrm{~B}$ & B & 4 & & $\mathrm{~B}$ \\
\hline 26 & $x^{2}, \cdots$ & & & ST & 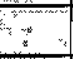 & & & \% & $\mathrm{B}$ & & & $B$ & $B$ & & $B$ & is & ST & $\mathrm{B}$ \\
\hline 27 & 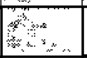 & & 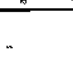 & 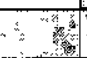 & ") & & 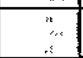 & F & $\mathrm{B}$ & & & 3 & $\mathrm{~B}$ & B & $B$ & w" & & $B$ \\
\hline 28 & 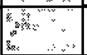 & & & 47 & $\therefore$ & & & 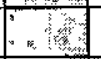 & B & & & $5 y^{2}$ & $B$ & $\mathrm{~B}$ & $B$ & $\therefore$ & & $B$ \\
\hline 29 & 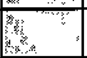 & & 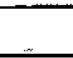 & 4 & 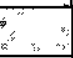 & & $\vdots$ & N & is & & $\because$ & 8 & $\mathrm{~B}$ & $\mathrm{~B}$ & $B$ & w & & $B$ \\
\hline$\overline{31}$ & 4 & & & 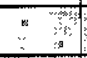 & $\ldots$ & & 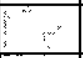 & $=4$ & 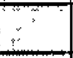 & & & 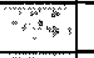 & $\mathrm{B}$ & $\mathrm{B}$ & $\mathrm{B}$ & 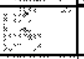 & & $\mathrm{B}$ \\
\hline 32 & $\begin{array}{lll}36 \\
3\end{array}$ & & & $\therefore$ & th & & & $\because y$ & s. & & & $\therefore 6$ & $\mathrm{~B}$ & B & $B$ & ? & - & \\
\hline 33 & 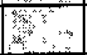 & & & $B$ & 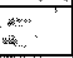 & & $\therefore$ & $=0$ & $\mathrm{~B}$ & & & $x^{2}$ & $B$ & $\mathrm{~B}$ & $\mathrm{~B}$ & 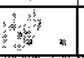 & & $\mathrm{B}$ \\
\hline 34 & 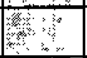 & & & (1) & & 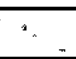 & & M. & ge & & 4 & $v^{2}$ & $\mathrm{~B}$ & $\mathrm{~B}$ & $B$ & 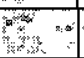 & & 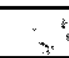 \\
\hline 35 & $z^{2}$ & & & (4) & 4 & $\therefore$ & $\Rightarrow$ & $\begin{array}{ll}3 \\
\gamma^{2}\end{array}$ & & & 9 & 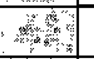 & $B$ & $\mathrm{~B}$ & $B$ & 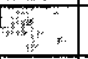 & & 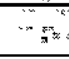 \\
\hline 36 & 96 & & & $=0$ & $a_{1}$ & & +4 & -7 & $B$ & & : & $x^{2} y^{2}$ & $\mathrm{~B}$ & $\because "$ & . & 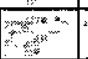 & 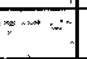 & $B$ \\
\hline 37 & 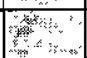 & & & 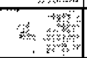 & B & & 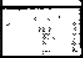 & $y^{2}$ & $B$ & $\therefore$ & (x) & $y^{3 x}$ & $B$ & ! & $\mathrm{B}$ & m & & $B$ \\
\hline 38 & $x^{2}$ & $\mathrm{~B}$ & & $=4$ & 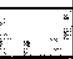 & & $\therefore$ & 5 & $\mathrm{B}$ & & $\therefore$ & ws & $B$ & & $B$ & Fon & 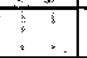 & B \\
\hline 39 & 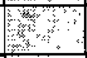 & $S$ & - & 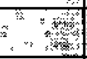 & 8 & $\ldots$ & $\therefore$ & ש: & $\mathrm{B}$ & & $\Rightarrow$ & $\mathrm{B}$ & $\mathrm{B}$ & $\because n$ & $B$ & 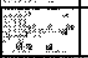 & & $\mathrm{B}$ \\
\hline 40 & 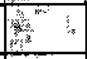 & $B$ & & $\mathrm{~B}$ & $n^{x}$ & $B$ & & $=2$ & $\mathrm{~B}$ & & 3 & $\mathrm{~B}$ & $\mathrm{~B}$ & & $\mathrm{~B}$ & \% & $\because$ & $\mathrm{B}$ \\
\hline 41 & 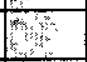 & & & 3 & 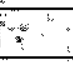 & $B$ & & Fin & $\mathrm{B}$ & & $B$ & 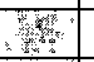 & $\mathrm{B}$ & & $B$ & क & 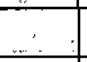 & $\mathrm{B}$ \\
\hline 42 & 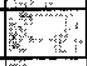 & & & 3 & $F^{n}$ & & $\therefore$ & \begin{tabular}{|l|l} 
\\
$\vdots$ \\
$x$
\end{tabular} & $\mathrm{~B}$ & & & 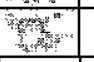 & $\mathrm{B}$ & $\mathrm{B}$ & $\mathrm{B}$ & w & & $\mathrm{B}$ \\
\hline 43 & 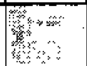 & & 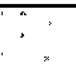 & 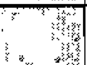 & $\therefore$ & & $B$ & & B & & & $B$ & $\mathrm{~B}$ & & $B$ & $\because$ & 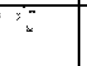 & $B$ \\
\hline 45 & s. & & 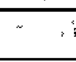 & 4 & $=x$ & & $\therefore=$ & $=1$ & $B$ & 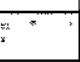 & . & W & $\mathrm{B}$ & $\mathrm{B}$ & $B$ & W & & $B$ \\
\hline 46 & $\sqrt{5}$ & $\therefore$ & : & $B$ & $\because:$ & & & . & $B$ & & & $4 x^{2}$ & $\mathrm{~B}$ & $\mathrm{~B}$ & $B$ & 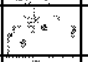 & & $\mathrm{B}$ \\
\hline 47 & ments & & $\therefore$ & $B$ & 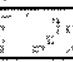 & & 3 & 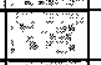 & $B$ & & & 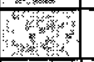 & $\mathrm{B}$ & $\mathrm{B}$ & $B$ & P: & 7 & $B$ \\
\hline 48 & 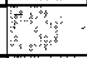 & & $?$ & 78 & 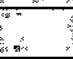 & 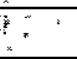 & & sing & $B$ & $\because r$ & 3 & sing & $\mathrm{B}$ & $\mathrm{B}$ & $B$ & (3) & & $\mathrm{B}$ \\
\hline 49 & 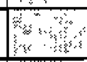 & 5 & $\omega_{n}$ & $n^{2}=$ & $6^{3}$ & & $\begin{array}{ll}x \\
2\end{array}$ & 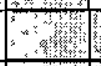 & & & 3 & 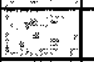 & $\mathrm{B}$ & $\mathrm{B}$ & $B$ & 烈 & & $B$ \\
\hline 50 & 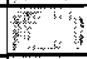 & & $\therefore$ & 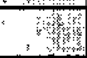 & s" & & 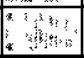 & 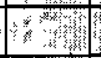 & . & $\therefore$ & $\therefore:$ & mans & $\mathrm{B}$ & $\mathrm{B}$ & $B$ & a & & $\therefore$ \\
\hline 51 & Pin, & & 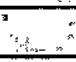 & Fit & , & & 4 & 5 & B & $\therefore$ & ming & in & $\mathrm{B}$ & $\mathrm{B}$ & $B$ & 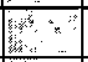 & $x^{2}+4$ & $B$ \\
\hline 52 & W & & : & Why & 5 & & $\mathrm{~B}$ & Wh & $B$ & $B$ & $\because 1$ & 4 & $\mathrm{~B}$ & & $B$ & Fing & $\because "$ & $B$ \\
\hline 53 & 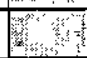 & & & - nd & 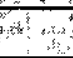 & 5 & 8 & III & B & $\because$ & 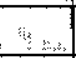 & $B$ & $B$ & 4 & $\mathrm{~B}$ & Fin & & $B$ \\
\hline 54 & : & & & , and & 4 & & $\therefore$ & and & $B$ & $B$ & & B & B & & $B$ & Fis. & $\therefore$ & $B$ \\
\hline 55 & F. & & 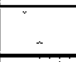 & $\mathrm{B}$ & $\therefore$ & 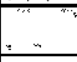 & $\ldots$ & W & $B$ & & $\therefore$ & $3^{2}$ & $\mathrm{~B}$ & & $\mathrm{~B}$ & 3 & $n$ & $B$ \\
\hline 56 & (4) & & 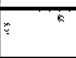 & $\mid$ & 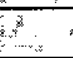 & & $\because$ & $x^{2}$ & $B$ & & & $2 x^{2}$ & $\mathrm{~B}$ & & 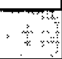 & $y^{2}$ & & $B$ \\
\hline 57 & . & & $\because$ & 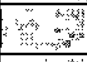 & 2 & & $\because$ & 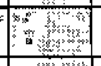 & $B$ & & & 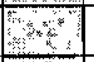 & $\mathrm{B}$ & $B$ & $B$ & . & & $B$ \\
\hline 58 & ? & & & $x^{2}$ & $\therefore$ & & $B$ & 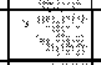 & $B$ & & 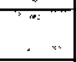 & $x^{3 i}$ & $B$ & $B$ & $B$ & $y^{2}$ & & $B$ \\
\hline 59 & $\cdots$ & & & $B$ & $\therefore$ & & 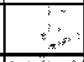 & , & $B$ & & 3 & $-\infty$ & $B$ & $B$ & $B$ & $"$ & $\frac{3}{3}$ & $B$ \\
\hline 60 & $\mathrm{~B}$ & & & ד' & 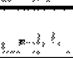 & $\mathrm{B}$ & 4 & $x^{\circ}$ & $B$ & & , & 86 & $\mathrm{~B}$ & $\therefore$ & B & $E \div$ & & $B$ \\
\hline 61 & 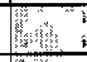 & & & $B$ & 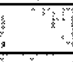 & & $\because 4$ & 8 & $B$ & & 政 & 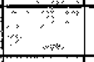 & $B$ & $\mathrm{~B}$ & $\mathrm{~B}$ & 6 & 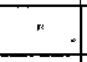 & $\mathrm{B}$ \\
\hline 62 & , 3 & & $\because$ & 3 & 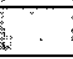 & 9 & $\therefore$ & , & $\mathrm{B}$ & & $\therefore$ & 3 & $B$ & $\because{ }_{\mathrm{B}}$ & $\therefore$ & ? & 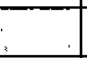 & $\mathrm{B}$ \\
\hline 63 & $\because n$ & & 4 & ST & $\because$ & & 13 & Whin & $\mathrm{B}$ & & $\because 3$ & B & $B$ & ${ }^{4}$ & $\mathrm{~B}$ & 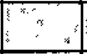 & i & $\mathrm{B}$ \\
\hline 64 & $y^{\prime}$ & & & $44^{2}$ & & . & 3 & $\because 6$ & $B$ & $\because$ & $d i$ & $s_{2}: A$ & $B$ & $B$ & $B$ & 8 & 4 & $\mathrm{~B}$ \\
\hline $\begin{array}{l}\text { Jumlah } \\
\text { maksimum } \\
\text { yang } \\
\text { dibutuhkan } \\
\text { untuk } \\
\text { mengikuti } \\
\text { training }\end{array}$ & 6 & 6 & 15 & 15 & 15 & 15 & 15 & 15 & 60 & 15 & 15 & 15 & 60 & 60 & 60 & 6 & 6 & 60 \\
\hline
\end{tabular}

Sumber : Data Primer Tahun 2011 (Diolah) 
Keterangan :

\begin{tabular}{|c|c|c|c|}
\hline ] & Tidak Membutuhkan Pelatihan : T & 1. Studi Lanjut S1 & $\begin{array}{l}\text { 11. Sertifikasi Pengadaan } \\
\text { barang/jasa }\end{array}$ \\
\hline ] & Butuh Pelatihan : B & 2. Studi Lanjut D3 & $\begin{array}{l}\text { 12. Ketrampilan Manajerial } \\
\text { (Lanjut) }\end{array}$ \\
\hline ] & Sedang Mengikuti Pelatihan : S & 3. Sertifikasi SAP Keuangan & $\begin{array}{l}\text { 13. Ketrampilan Manajerial } \\
\text { (Standar) }\end{array}$ \\
\hline ] & Sudah Dilatih : SD & 4. SIMAK & $\begin{array}{l}\text { office: MS Word dan } \\
\text { Excel }\end{array}$ \\
\hline$T$ & Sudah Terlatih \& Dapat Melatih Orang Lain : & 5. SIMFOIN & 15. Service Excellence \\
\hline & Tidak Membutuhkan Pelatihan : T & 6. SIMKEU & 16. Bahasa Inggris \\
\hline & & 7. SIMPUS & 17. Pemrograman Web \\
\hline & $\theta$ & $\begin{array}{l}\text { 8. SIMPEG } \\
\text { 9. Manajemen Kantor dan } \\
\text { Pengarsipan } \\
\text { 10. Olah pustaka }\end{array}$ & $\begin{array}{l}\text { 18. Workshop Audit Mutu } \\
\text { 13. Ketrampilan Manajerial } \\
\text { (Lanjut) } \\
\text { (4. Ketrampilan Manajerial } \\
\text { (Standar) }\end{array}$ \\
\hline
\end{tabular}

Tabel 5 menunjukkan bahwa pelatihan dengan materi ketrampilan manajerial tingkat dasar, penggunaan Microsoft office : MS Word dan Excel, service excellence dan workshop audit mutu, sebaiknya diikuti oleh semua tenaga kependidikan tetap. Hal ini disebabkan karena materi tersebut merupakan kompetensi dasar yang harus dimiliki oleh seorang tenaga kependidikan untuk dapat berkinerja secara baik. Apabila jumlah tenaga kependidikan yang dimatrikkan lebih banyak dibandingkan dengan jumlah maksimal tenaga kependidikan yang dapat dilatihkan untuk suatu materi tertentu, itu artinya FEUII dapat memilih tenaga kependidikan yang akan dilatihkan berdasarkan skala prioritas kebutuhan unit dan atau kinerja.

Pelatihan dapat dilaksanakan secara efisien dengan menggunakan pelatih dari dalam FE Ull yang memang memiliki kompetensi di bidang terkait. Tabel 5 menunjukkan bahwa FE UII memiliki tenaga kependidikan tetap yang telah memiliki kualifikasi sudah terlatih dan dapat melatih orang lain (ST) untuk materi SIMAK, penggunaan Microsoft office : MS Word dan Excel dan pemrograman Web. Sedangkan materi yang lain dapat diambilkan pemateri dari staf pengajar di FE UII, kecuali untuk sertifikasi pengadaan barang dan jasa. Budaya untuk mau berbagi pengetahuan dan ketrampilan dengan anggota organisasi lainnya, haruslah didorong kemunculannya pada setiap tenaga kependidikan. Oleh karenanya, FE UII perlu untuk mendisain kompensasi untuk mendorong munculnya semangat tenaga kependidikan untuk mendapatkan dan membagikan pengetahuan dan ketrampilan baru yang mendukung peningkatan kinerja Budaya ini akan mendukung terwujudnya learning organization, yang didefinisikan oleh Garvin (1993) sebagai organisasi yang terampil dalam menciptakan, mendapatkan dan mentransfer pengetahuan dan ketrampilan sehingga mempengaruhi perilaku. Hal ini diharapkan akan meringankan beban bjaya yang harus ditanggung Ull untuk mengembangkan tenaga kependidikan, untuk memenangkan persaingan.

\section{KESIMPULAN}

Penelitian yang telah dilakukan menghasilkan kesimpulan antara lain: (1) berdasarkan data semester ganjil 2011/2012, rasio tenaga kependidikan : mahasiswa, di FE UII adalah 1:77, berada pada kategori ideal; (2) jumlah tenaga kependidikan di FE UII yang memiliki usia produktif $>4$ tahun sebanyak 4 (empat) orang; (3) jumlah tenaga kependidikan di FE UII yang saat ini bekerja pada pekerjaan yang tidak sesuai dengan keinginannya sebanyak 2 (dua) orang; dan (4) jumlah tenaga kependidikan di FE UII yang memiliki keinginan untuk mengembangkan diri dan meraih/menduduki pekerjaan yang lebih tinggi sebanyak 11 orang. 
Mempertimbangkan hasil penelitian tersebut, peneliti merekomendasikan saransaran antara lain: (1) FE UII perlu menyediakan kesempatan untuk konșeling bagi tenaga kependidikan yang merasa tidak sesuai dengan pekerjaan yang diembannya saat ini; (2) FE UII perlu memberikan penyuluhan atau pendidikan terhadap tenaga kependidikan terkait kebutuhan untuk tumbuh dan berkembang; dan (3) FE UII perlu untuk mendisain kompensasi untuk mendorong munculnya semangat tenaga kependidikan untuk mendapatkan dan membagikan kepada rekan kerjanya, pengetahuan dan ketrampilan baru yang mendukung peningkatan kinerja.

\section{DAFTAR PUSTAKA}

Appelbaum, Steven H.\& Kamal, Rammie (2000) "An Analysis of the Utilization and Effectiveness of Non-Financial Incentives in Small Business", The Journal of Management Development, Bradford: Vol 19, Iss 9/10, p 733.

Bohlander, George \& Snell, Scott, (2010) Managing Human Resources. Thomson SouthWestern: USA.

Garvin, David (1993) "Building A Learning Organization", dalam Harvard Business Review, Juli-Aug, p 78-91.

Handoko, T. Hani (2011) Manajemen Personalia dan Sumber Daya Manusia. BPFE: Yogyakarta

Kementerian Pendidikan Nasional Badan Pengembangan Sumber Daya Manusia Pendidikan dan Penjaminan Mutu Pendidikan Pusat Penjaminan Mutu Pendidikan Bidang Dikmen dan Dikti, Evaluasi Mutu Internal Perguruan Tinggi Indonesia: Pedoman Pengisian Alat Evaluasi Mutu Internal Perguruan Tinggi Indonesia, Draft Versi 1.1

Kini, Ranjan B. \& Hobson, Charles J. (2002). "Motivational Theories and Succesful Total Quality Management". Dalam International Journal of Management. Poole: Vol 19, Iss 4, p 605.

Karatepe, Osman M \& Ekiz, Erdogan H. ( 2004) "The Effects of Organizational Responses to Complaint on Satisfaction and Loyalty: A Study of Hotel Guests in Northern Cyprus". Managing Service Quality. Bedford:Vol. 14, Iss 6, p 476.

Nawawi, Hadari, (2008) Riset Sumber Daya Manusia Untuk Bisnis Yang Kompetitif. Yogyakarta: UGM.

Prawirosentono, Suyadi. (1999) Kebijakan Kinerja Tenaga Kependidikan. Edisi Pertama. Yogyakarta: BPFE.

Wren, Daniel A, (1994) The Evolution of Management Thought, New York: John Wiley \& Sons. 